Федор Б. Марјановић ${ }^{1}$

Универзитет у Новом Саду

Финозофски факултет

\title{
БАРОКНИ МОТИВ ОГЛЕДАЛА У РОМАНУ СЕОБЕ МИЛОША ЦРЬАНСКОГ
}

Апстракт: Рад се бави значењем које огледало добија у структури романа Сеобе Милоша Црнанског. Уначину употребе мотива препознајемо типичне барокне карактеристике. Укюижевноумјетничком систему Милоша Црғанског барок добија значење слободе стила и снажних осјећана, а основне ознаке су „меланхолија" и „сјенка". На основу примјера пјесничтва Џива Бунућа и Бованија Каналеа и сликарства Аукаса Фуртенагела и Жоржа де ла Тура увиђа се да се у бароку огледало употребљава као ознака пролазности с основном поруком mетепto тогі. УСеобама мотив огледала користи се приликом карактеризаиије Вука Исаковича и Аафине. У сижкјној линији госпоже Аафине огледало добија значете смрти, јављајући се у функииј тене антиципације или реализачије. Са друге стране, огледало означава подвојеност Вуковог лика на нивоима српскоаустроугарско, унутраште-спољаште, духовно-тјелесно, пасивно-активно и младост-старост. Уз анализу текста дати су и аналогни примјери употребе мотива огледала у барокном сликарству (Каравађо и Бернардо Строии).

Къучне ријечи: Милош Црғански, Сеобе, огледало, барок.

\section{1. УвоА}

У тексту Сеоба Милоша Црњанског Ава пута се експлицитно указује на присуство барока: „Брзо је рашчистио Авориште, обрасло бршьаном, поА великим прозорима мрке, барокне зграАе” (1978: 34); „Помислив на ту драгоцену ствар, онда му се јави јасно у сећању, са минијатурним портретом, који су држали јеАан барокни Херкул, са буџом у руци, и јеАан Марс, у руци са штитом, на коме је урцала глава Медузе, Аок је на њима кебдела крилата ПобеАа,

${ }^{1}$ АокторанА Фимозофског факултета Универзитета у Новом СаАу. ИмејА-аАреса: marjanovicfedor@ gmail.com. 


\section{Федор Б. Марјановић}

са ванредним ружичастим грудима, дувајући у фанфару" (1978: 113). Тиме се обиьежава културно-историјски контекст романескне фабуле. Иако је сматрао Аа роман није историјски, Црњански је велику пажњу посветио историјској вјеродостојности: „КаА се говори о једном човеку, ими жени, у осамнаестом веку, писац мора да буде историјски. Мора знати какву дугмад имају на капуту и какву свећу ими мампу носе у сутону, па чак и како се изражавају. Само све то ипак не значи да је то историја, да је то историјски роман” (19996: 520). Пишчева брига о историјски вјеродостојним детаьима примијећена је и у књижевно-теоријским радовима. „На пример, сат Вука Исаковича је 'округао као јаје' - сат старинског, за данашње часовнике неуобичајеног облика. Чак и у такозваним 'ситницама' писац строго води рачуна о томе да код читаоца изазове утисак одређене 'историјске' атмосфере” (Мимошевић 1988: 102).

Из перспективе историје умјетности, период описан у Сеобама представља крај умјетности барока. „Baroku prethodi renesansa, a za njim sledi novi klasicizam koji počinje da se pomalja od sredine 18. veka. Sve u svemu, barok traje oko dve stotine godina" (Velflin 2000: 11). САичну периодизацију можемо наћи у Јансоновој Историји уметности, гаје се трајање овог периода грубо омеђује између 1600. и 1750. године (1970: 405). Међутим, према другим кмасификацијама, барок доминира у XVII вијеку, а у XVIII је такође доминантан стил, али у облику који се назива високи барок ими рококо, на који је утицама фимософија просветитеьства и култ разума XVIII вијека. „Barok postaje sve manje naglašen i sve rascjepkaniji, pa umjetnost gubi utjecaj i uvjerljivost i od nje se sve više očekuje ispunjenje puke estetske uloge tumačenja i prenošenja misli putem ljepote. [...] U relativno kratkom razdoblju barok se razvio u visoki barok, također poznat pod nazivom rokoko, koji se osobito primjenjuje u vezi s arhitekturom i dekorativnim umjetnostima” (OPU 2006: 294). Јасно је Аа постоји велика диспропорција између основног тона рококоа и Сеоба. Она произилази из разлике између романа и Мемоара Симеона Пишчевића, основног прототекста и производа описаног периода:

Пишчевићеви Мемоари су, наиме, претежно прича о награђеној војничкој врлини, а не о блату искуства и небесима чежње. [...] Укратко, за њега историјско искуство није мочвара и блато него марш ка вишим чиновима у отменом аустријском и руском официрском кору, те ни Русија није за њега „надземањско царство”, ни симбол „сладости православља", него каријера (Ковевић 2007: 118-119). 
Иако се на формалном пцану аутор придржавао историјских чињеница и Аатума, на плану садржаја унио је промјене које су одговараце његовом пјесничком сензибимитету и погледу на свијет. Барок који примјећујемо у роману јесте барок према којем је Мимош Црњански имао више афинитета и који је могао сматрати себи бциским. У питању је барокно осјећање промазности свијета, што га је писац препознао у дјелу Микеланђела, а које је преовладавало у XVI вијеку (в. Velflin 2000). Један од основних знакова таквог погледа на свијет јесте и огледало, које је својим посматрачима преносило поруку о краткоћи живота и близини смрти. Исту функцију мотива огледама препознајемо и у Сеобама. Осим што на специфичан начин означава епоху на залазу, огледало у роману постаје носимац универзацних порука, као и јеАан од основних елемената карактеризације главних јунака.

Циь овог рада јесте Аа проучи функцију мотива огледала у структури романа и утврди његове барокне коријене. Рад ће бити подијељен на три дијела, оА којих ће се први бавити значењем које барок добија у структури дјела Мимоша Црњанског. Аруги дио рада биће посвећен испитивању значења које огледало добија у умјетности барока. Кроз неколико примјера, у овом дијелу ће бити икустрован тип структура барокних умјетничких дјема које укьучују мотив огледала. Трећи дио ће бити посвећен конкретној функцији огледама у роману и испитивања барокности његовог садржаја, уз навођење примјера из умјетности барока који формално-садржински одговарају анализираним сценама.

\section{2. Црњански и барок}

Барок, односно барокно позориште, Црњански помиње већ у свом есеју „Бивше кулисе” (Црњански 1999а: 395-397), на основу чега је Мирјана Миочиновић препознала присуство барока у његовој драми Маска: „Сценски простор Маске, њена визуелна страна, декорум, јесте помацо ванвременски простор раскоши за који зна само барокна сцена” (2005: 228).

Иако ово потврђује присуство барокног умјетничког искуства већ у најранијим дјелима Црњанског, о пишчевом односу према бароку више сазнајемо из Книге о Микеланђелу. ${ }^{2}$ Аа бисмо утврдими пишчев став, навешћемо некомико исказа о барокној природи Аавида и Пијете: 1) „КаА се, међутим, боље

\footnotetext{
${ }^{2}$ Иако је недовршену Кюигу о Микеланђелу Црњански писао пред крај живота, Аакме много након Сеоба, по сопственом свједочењу, Микеланђемов рад је почео проучавати и прије писања романа. „Па ја живим педесет година са Микеланђелом. Био сам 1912. у Италији и, одонда, увек" (Црњански 19996: 572). Са Аруге стране, без обзира на хронологију, овдје нас занима значење барока које улази у умјетников језички систем. Без обзира на то Аа ки је то значење
} 
загледа, то није скулптура античке хармоније, него барокног идеала. Необична" (Црњански 2008: 14).2) „А осим тога што је та скулптура необична у ренесансу - необична, Аакме барокна. Пре свега зато, што је Микеланђело од малог Аавида начинио Аавида, који је виши, стасом, од Голијата. Та је идеја, мени се чини, барокна” (Црњански 2008:15). 3) „Има у том Аавиду, кажем, нека $\triangle$ ВОСТРУКОСТ бића, које у античком идеацу, и античкој скулптури нема, па је називам барокном” (Црњански 2008: 17). 4) „Антички кип је миран, мирна хармонија, ведрина, у таквом кипу у мепом телу и душа је лепа. Микеланђелов Аавид је набрекао, романтично, не антички, од мишића и беса" (Црњански 2008: 17). 5) „У Аивьој коси и Аивьим ноздрвама тог Аавида има питорескног, театранног, дакме барокног, а највише у очима тог барока" (Црњански 2008: 17). 6) „Скулптура Микеланђелова је увек усамьена. Тужна. А каА о смрти

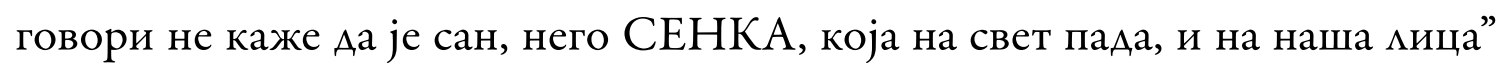
(Црњански 2008: 18). 7) „А што се тиче Микеланђелове меланхолије, мени се чини много већа, него та његова, извикана terribilita” (Црњански 2008: 18). 8) „А зачудо ту тугу имају у себи и све очи Микеланђела, и на његовим најгорим портретима” (Црњански 2008: 19). 9) „Та Мадона, тако млада, мирна, мепа са раширеним снажним коленима, са тим сенкама на мицу, мешавина готике и античких богиња са надгробним драперијама - није више ренесанса. То је нешто ново: Микеланђемо” (Црњански 2008: 66). 10) „Има у њој сувише мисли и осећања, драме, интелекта, а нарочито СЕНКИ, Аа би се могла звати античка и класична и ренесансна. То је МЕ ААНХОАИЈА” (Црњански 2008: 67). 11) „Тај антички барок је питање формално, спољно, александријско, теа-

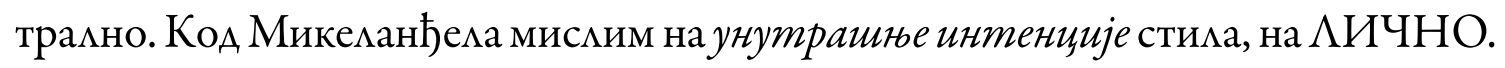

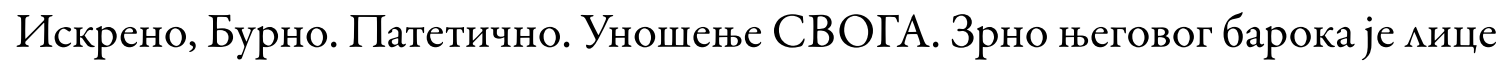
његовог човека, жене - јаука, као што га има, иако не у мрамору - у поезији, код Таса" (Црњански 2008: 67).

На основу садржаја наведени искази могу се сврстати у Авије семантичке категорије: а) оне који се односе на стил барока (искази 1, 2, 4, 9) и б) исказе који се односе на садржину барока $(3,5-8,10)$. Исказ 11 припада објема групама, пошто се у њему говори о корелацији стила и садржаја у бароку. Такође, Црњански барок одређује као опозицију антици у исказима 1, 4 и 11.

Из стилистичке перспективе, видимо Аа Црњански под бароком подразумијева све што је „необично” и „ново”. Под тим подразумијева Аиспропорционацност, хипердимензионираност, „набрекцост оА мишића и бијеса”, питореск- 
ност и театралност, односно живописност и монументалност (в. Velflin 2000). Барокни стил у односу на антички успоставња дихотомију која функционише на релацијама хармонија-диспропорција ${ }^{3}$ и спољашње-унутрашње, односно формално-садржајно, при чему хармонични стил антике заАржава на нивоу форме, Аок Аиспропорционални стил барока оАређује саАржину Ајела и његову емоционалну димензију.

Карактеристике барокног стима које издваја Црњански мако је препознати у стилу Сеоба. Иако је структура и језичка организација, са честим понавьањима на почетку и крају романа, изузетно строга, она одудара оА класичне романескне схеме, прије свега што се у Сеобе транспонује језик поезије, на шта је указао Новица Петковић у цитату који слиједи:

Јер, Аовољно је само мало помније размотрити и проверити односе у саставу његове типичне реченице, и одмах се разабира да ту, уз обавезна синтаксичка правила нашег језика, саучествују и нека из стиха пренета ритмичка начела. Не, додуше, из стиха уопште, него ритмичка начема из онога посебног стиха који је Црњански 20-их година израдио, и који је свој најчистији облик добио у поеми Стражилово (Интернет: 116).

Такав језик нарушава форму кмасичног романескног израза, док са Аруге стране омогућава наратору да кирским изразом изнесе мисли, осјећања и запажања својих јунака:

Пренети овакве опажаје - који су по својој природи кични и непоновьиви - у уједначен говор вазда истог а безмичног аутора није могуће, или бар није на књижевно уверьив начин могуће, ако језичка изражајна средства нису посебно преудешена. И не само то. Ти се саАржаји, наиме, у облику у коме их налазимо, тек у ауторовоме говору образују - он их образује. Овде се, на појачан начин, дешава оно што се у књижевној уметности увек дешавало, само што се не може сваки пут довољно јасно пратити: Аа се изражени предмет конституише заједно са средствима која га изражавају, Аа једнога без другога нема (Петковић, интернет: 138).

\footnotetext{
${ }^{3}$ Аа став Црњанског, када је у питању Аавидова диспропорционалност наспрам античке хармоничности, није пишчева креација, потврђено је у историји умјетности на основу поређења Микеланђемовог и Бернинијевог Аавида са скулптуром Ааокона. „Ako uporedimo Berninijevog Davida s Michelangelovim i upitamo se koji je bliskiji pergamskom frizu ili Laokonovoj grupi, moraćemo dati svoj glas Berniniju. Njegovom liku i helenističkim delima zajednički je onaj sklad duha i tela, pokreta i emocije, koje je Michelangelo tako upadljivo izbegavao" (Janson 1970: 410).
} 
Овако организованом језичком структуром заправо се остварује „унутрашња интенција стима”, чиме се потврђује барокност романа, у оном значењу које бароку даје писац. Са друге стране, у интервјуима Црњански је инсистирао на томе Аа његови романи нису мирски у толикој мјери колико је истицано, а

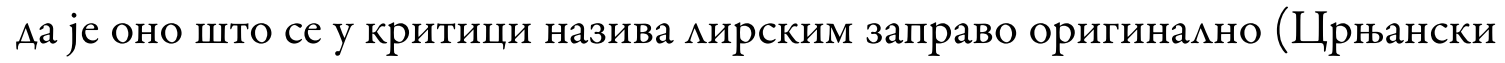
19996: 519), ики „Аично”, „своје”, барокно (исказ 11).

Основу садржаја барока Црњански је видио у тузи и меланхолији, осјећањима која прожимају велики дио опуса Црњанског, а посебно Сеобе. За наше истраживање веома је занимьиво Аа писац подвцачи значењску еквивалентност појмова смрти и сјенке, која је чест мотив у његовом дјелу. Такав став Црњански је врло мако могао преузети оА једног оА најважнијих теоретичара барока Хајнриха Велфмина, који је почетке овог стима видио управо у Микеманђеловом дјелу. Проучавајући Микеманђелове скулптуре у капели МеАичи, његово расположење одредио је слично као и Црњански. „Ті likovi noći i dana, večeri i jutra, onako kako tu leže, prigušeno uzdišući i otimajući se snu, udova grčevito stegnutih ili beživotno opuštenih, prožeti su dubokim nespokojstvom, raspoloženjem koje se kod Mikelanđela ponavlja svuda, kako u njegovim pesmama tako i u njegovim figurama" (Velflin 2000: 90).

У контексту рада још је занимьивије како Вецфмин описује „постренесансну озбиьност”: „dolazi do religiozne samospoznaje; svetovno se ponovo nalazi u suprotnosti sa duhovnim i svetim; neobuzdano uživanje u životu prestaje; Taso za svoj hrišćanski ep odabire junaka umornog od sveta" (2000: 90). Овим се обасјава нова структурамна повезаност Тасовог епа Ослобођени Јерусалим и Сеоба Црњанског, пошто се у оба дјела у центар ратних дешавања поставља „јунак уморан оА свијета”. Према тумачењу Црњанског Тасо је био сродник Микеманђелов, тако да је Аавид „човек Таса, Бруна, Кампанеле” (2008: 18), док се ријеч 'сјенка' „у Италији, Ава пута, понавља. КоА Авојице који су покривени сенком целог живота, иако у Италији, за сваког другога, има Сунца. То су Микеланђело и Тасо. Кажу: сенка. Ombra” (Црњански 2008: 6).

Салржински елементи барока, осјећање меланхолије и туге, сјенка као знак пролазности живота и смрти, присутни су у Сеобама, аци и у Аругим Ајелима Црњанског. Авострукост коју Црњански види у Аавидовом кику (исказ 3 ) имаће многи његови јунаци (укьучујући и Вука Исаковича). Зато нам његов однос према бароку помаже Аа проникнемо дубње у природу његовог стваралаштва. У том погледу закьучку Горане Раичевић у цитату који слиједи, о важности разумијевања значења барока у дјелу Црњанског, мало шта се може 
У кьучу његовог схватања барока као индивидуацизма, стварања као надахнућа, ефекта дела као доживљаја, и као меланхоличног али и побуњеничког става уметника према свету, може се објашњавати његова скмоност према романтичарској и експресионистичкој естетици, које опет искьучује свако схватање барокног као маниристичког, кончетистичког формализма, као рационалистичке поетике чије је занатство Црњански толико презирао (Раичевић 2005: 342).

\section{3. Огмедамо и барок}

Као симбол, огмедало има широк спектар значења, које се најчешће повезује с одразом истине. Међутим, у конкретном систему његово значење остварује се тек у саодносу с осталим елементима структуре. Огледало као семантички знак производи Авије врсте значења: 1) значење огледала које се остварује у његовом односу са сусједним знаковима и 2) значење сусјеАних знакова које се разобличава у огледацу. У језику барокне умјетности оно је одређено погледом на свијет који се окретао религиозној мистици и који је, за разАику оА ренесансе и њене крикатице carpe diem, својим конзументима поручивао: „Memento mori.”

Изузетно имустративан примјер употребе мотива огмеАала у књижевности барока јесте пјесма „Премијепа Јемена стара преА оглеАамом” Џива Бунића, у којој остарјела мирска јунакиња посматра свој одраз и пита се Аа Аи би Троја пала да ју је Парис видио такву каква је у тренутку док сједи преА оглеАалом. Основно значење које огледало у пјесми добија и рефлектује јесте значење пролазности. Због тога је у бароку оно првенствено повезано са феноменом времена, што је експлицитно исказано у пјесми Ђованија Канамеа „Време са огледалом у руци":

U ovom staklu koje držim odraz je taštog sveta

U svim mu menama, od stupa do prestupa;

Sad spremam nove oblike i likove (Todorović 2012: 16).

„Ogledalo je ovde upotrebljeno u kontekstu memento mori i treba da pruži odraz taštine ovoga sveta (u ovom staklu koje držim odraz je taštoga sveta) kao izraz ukora i opomene" (Todorović 2012: 17).

Овакав однос означавајућег и означеног још је експлицитнији у миковној умјетности барока. Као примјер наводимо портрет Хасна Буркхајма и његове супруге, који је насликао Аукас ФуртенагеА. „Već sama drška nosi ironičnu 


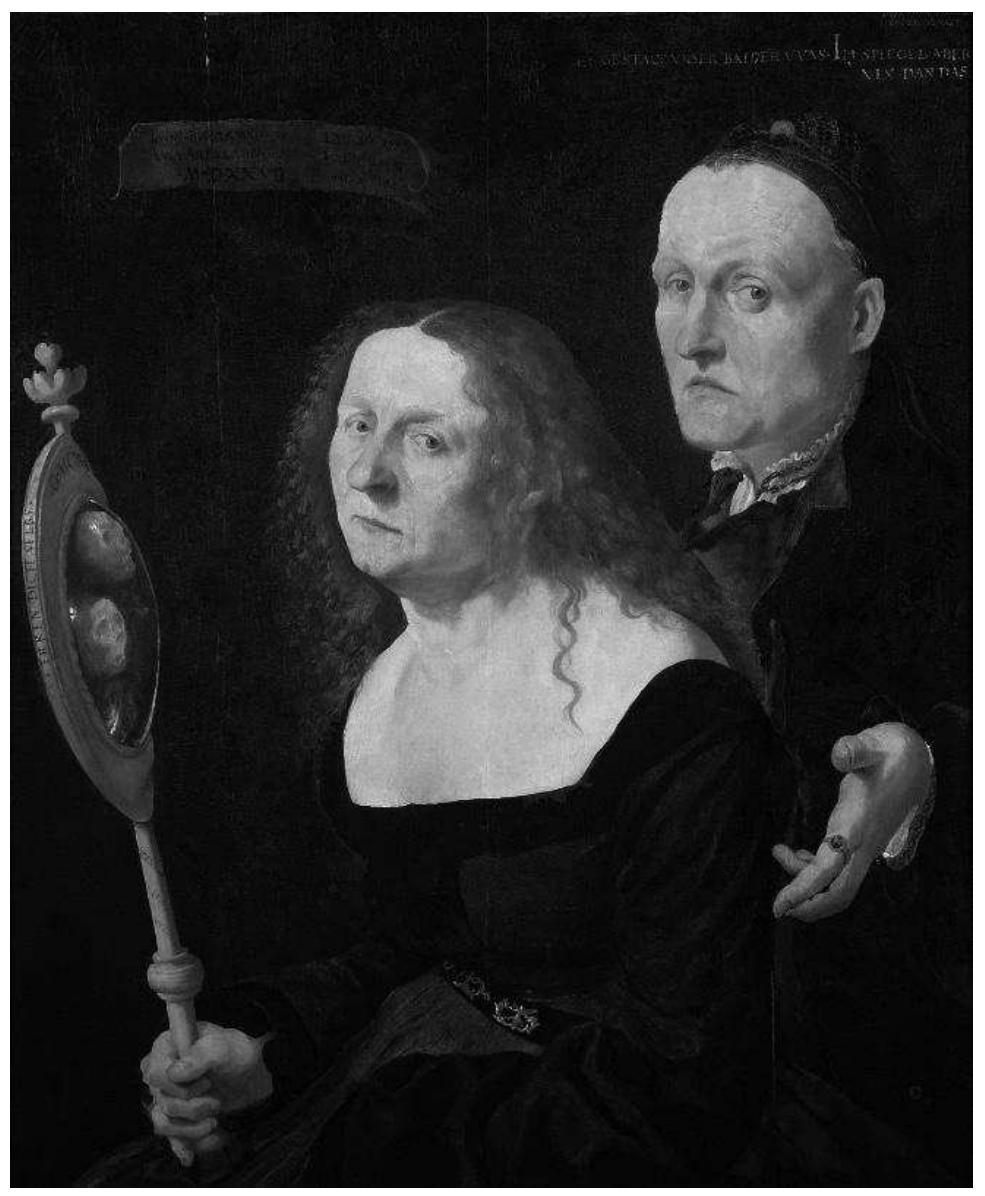

poruku - spes mundi (nada sveta) - a odraz opisuje tu nadu veoma upečatljivo. Kao da izviru sa dna tamnog jezera, dve svetlucave lobanje uzvraćaju pogled bračnom paru. Smireno držanje supružnika, njihovi spokojni pokreti, govore o tome da oni znaju da vreme prolazi i da je smrt neizbežna" (Todorović 2012: 20). Посматрач слике види одређен систем знакова што га представьају умјетник и његова жена, а који се прекодира у огмедалу. Иако дјелује утварно, садржај огледала је истина, јер упућује на оно што неминовно долази, а ьуди на портрету, њихова одјећа, ознака високог положаја у Аруштву заправо су илузије подложне промјени и пропадању.

Огледало се често појавьује у vanitas композицијама. „Та tema opsednutosti lepotom, starenjem i smrću često je obrađivana u slikarstvu u okviru 'vanitasa': prikaza devojaka koje zaljubljeno posmatraju svoj odraz, nehajno nalakćene na lobanju" (LMRS 2011:384). Овакву структуру препознајемо у Ае ка Туровом циклусу слика посвећеном теми МагАалене покајнице. У циклусу оА четири слике посебно су занимьиве Авије у којима се појавьује огледало. Значење ових слика формира се на њиховој међусобној опозицији. Заједнички елементи структуре слика јесу Ајевојка, огмедало, мобања и свијећа. На првој слици 
Барокни мотив огледала у роману Сеобе Милоша Црњанског
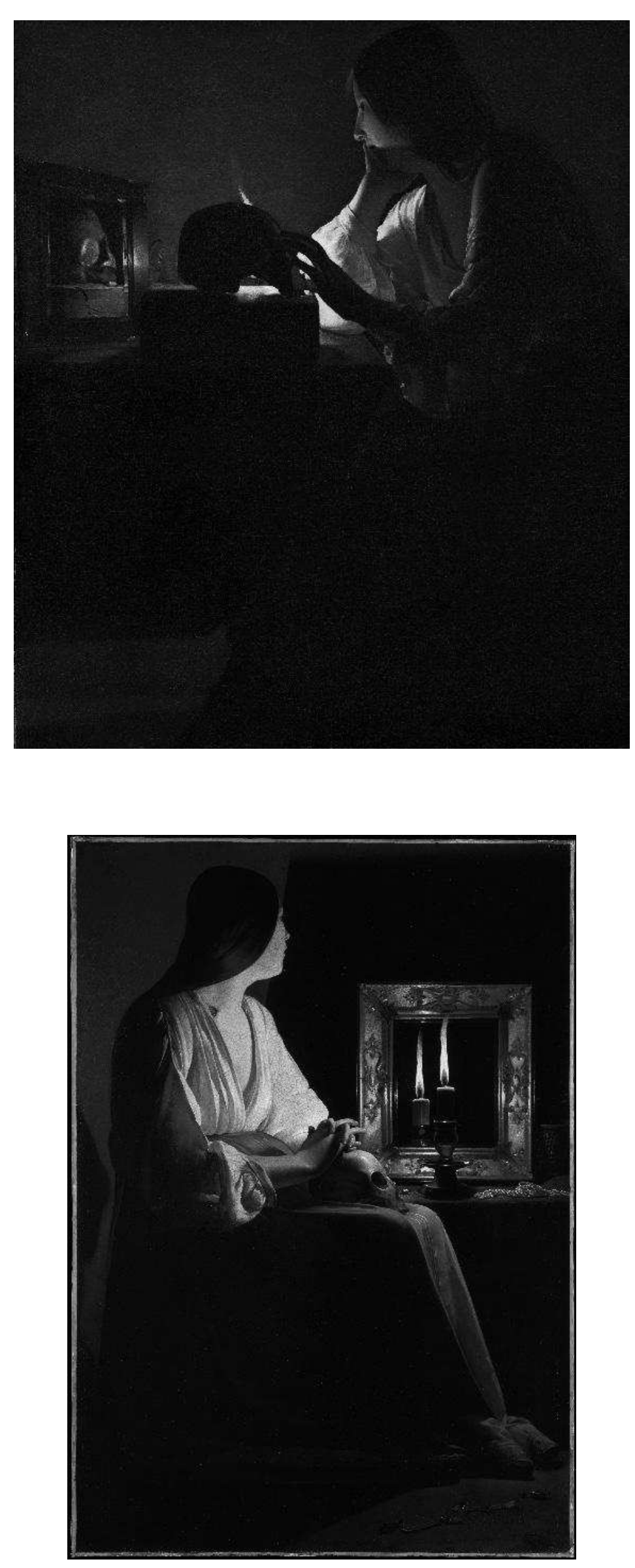

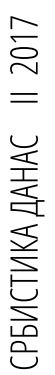


Ајевојка сједи у усправном положају са мобањом на крилу, а на другој слици Ајевојка сједи налакћена на сто, главе ослоњене на јеАну руку, Аок Аругом Аодирује мобању, поставњену високо на књизи која се намази на столу. Обје Ајевојке посматрају огмеАало, али на првој слици се на површини оглеАала види одраз пламена свијеће, а на Аругој мобања. Поред тога на првој слици, пламен свијеће као извор свјетла потпуно је изможен посматрачевом погледу, Аок је на другој заклоњен мобањом. У историји умјетности потврђено је да се структура прве слике заснива на контрастном значењу свијеће и мобање. „Glavne efekte stvara snažan kontrast između svjetla i sjene, a cijelo se djelo i zasniva na dijalogu suprotnosti, i to ne samo u slikarskom smislu. Zabliještena sjajnim svjetlom koje razbija tamu njene sobe, Magdalena čvrsto drži lubanju, simbol ispraznosti ovozemaljskog bogatstva, zagledana u izvor svjetlosti” (OPU 2006: 272). На основу њеног положаја, као на композиционој распоређености свијеће и мобање, и одраза у огмедалу, закьучујемо да је у првој слици приказана МагАалена која је Аошла Ао покајања, док на Аругој слици Магдалена тек почиње Аа контемплира о својој судбини. У оба случаја огледало преАставља централни елемент умјетничке структуре, а основно значење произилази из објекта који се одражава на његовој површини (свијећа ими мобања). Међутим, у оба случаја оно упозорава гледаоца на пролазност живота и протицање времена. „U zrcalu se ne odražava ništa osim svijeće koja dogorijeva, ukazujući na protjecanje vremena” (OPU 2006: 272).

Наведени примјери скуже као имустрација оне врсте релације означавајућег и означеног која производи значење пролазности, меланхолије и блискости смрти, релације чије ћемо присуство покушати да потврдимо у Сеобама. „S obzirom na to da je prizor kratkoće i trenutačnosti ljudskog veka istovremeno i jedna od manifestacija čudesnog, ogledalo se zaista može, zahvaljujući raznolikosti svojih pojavnih vidova, koristiti kao znamen baroknog poimanja vremena kao prolaznosti" (Todorović 2012: 43).

\section{4. Аафинино огледамо}

Описани кол који огледало има у бароку пренесен је у Сеобе. Препознајемо га у опису Аафининог огледања у ријеци. „Аан и ноћ протицала је ту широка, устајала река. И, у њој, њена сен” (Црњански 1978: 58). У овом примјеру функцију огмедала преузима ријека. Иако се сцена огледања своди на јеАну реченицу, она је један оА кьучних фактора изградње Аафининог кика. Важност ове реченице потврђује се и у чињеници Аа је писац употребљава као наслов 
трећег поглавьа романа, чија се важност у конструкцији Аафининог Аика састоји у томе што у њему нарација по први пут почиње да тече из њене перспективе. У том се сегменту поглавьа први пут помиње Аафинино име, чиме почиње њено развијање као самосвојне јунакиње, независне од погледа Вука и Аранђела, из чије се перспективе именује као „жена” ими „снаха”.

Са Аруге стране, када се синтаксичка структура субјекатске синтагме „широка, устајала река. И, у њој, њена сен”“ упореди са структуром наслова првог поглавља „Бескрајни, плави круг. У њему, звезАа”, препознаје се паралелизам који функционише на формахној еквивалентности, али и на значењској опозиционираности. У оба случаја наилазимо на двије синтагме у саставној вези, разАвојене тачком (с тим да се у Аругом примјеру налази и везник „и”). У првим синтагмама са мијеве стране центрацног члана нацазе се по Ава атрибута разАвојена зарезом, од којих први означава обим, односно квантитет центрацног

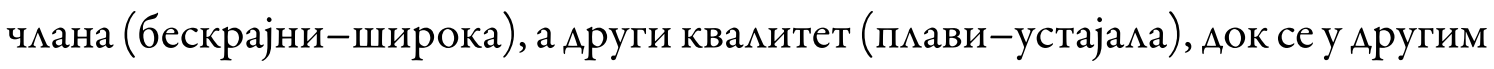
синтагмама централни чланови првих супституишу замјеницама које у прије-

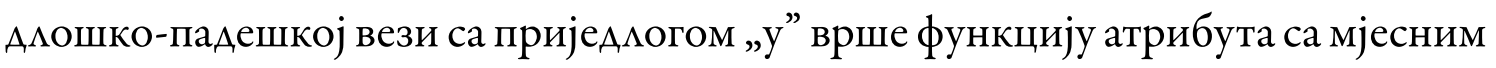
значењем. Аок се синтаксичке структуре пресликавају из јеАне конструкције у Аругу, на значењском пцану стварају се опозиције. Централни чланови, као основни значењски елементи (круг-ријека, звијезда-сјена), формирају се као знакови опозитног значења. Осим што се ова бинарна опозиција потврђује значењима њихових атрибута (бескрајни, плави - широка, устајала), контексти у којима су дати стварају још мноштво опозиција на конотационом нивоу, као што су горе-доье, небо-земьа, бесконачно-коначно, вјечно-пролазно. Из макроконтекста се открива још опозиција Вук-Аафина, која се односи на јунаке који виде описане знакове, и опозиција сан-јава, која се односи на стања у којима су их јунаци видјели. Из овога се може извући још шира опозиција мушко-женско, која одговара традиционалном приписивању значења небеског и Ауховног мушком принципу, а земаьског и материјацног женском. Из овога се закьучује да се госпожа Аафина као мик ствара као антипод своме мужу Вуку Исаковичу. Аакле, за разцику од Вука Исаковича, који своје идеале проналази у небеским сферама, Аафина је остварена као мичност која остварење својих снова тражи првенствено у материјацном. Небеско у њеним илеацима постоји, али оно је у уској вези с Вуком Исаковичем, с њиховим првим годинама брака.

На плану садржаја поставьа се питање шта заправо Аафина види у ријеци. У слици њене сјене Новица Петковић уочава „визуелно успоставьену метони-

${ }^{4}$ У овом случају тачка не означава границу двију реченица, већ њену парцелизацију, пошто синтаксички „и у њој њена сен” не може да буде самостална реченица. 


\section{Федор Б. Марјановић}

мичну везу" која се касније кроз паралемизме преноси и на Аруге етапе њеног живота. „Касније ће Аанима и недељама тело госпоже Аафине умирати пореА прозора изнаА воде, и из њега ће нестајати, отицати живот (из њега је 'отицаца крв и никакве јој бабице не помогоше') парацелно с отицањем широке и жуте реке" (Петковић: 111).

Међутим, контекст онемогућава тумачење Аафинине сјене у ријеци као реалног физичког објекта, с обзиром на то да је експиицитно наглашено Аа она заједно са ријеком тече „дању и ноћу”. Свакако Аа би се ноћу, уз свјетло пећи, могла видјети Аафинина сјена у ријеци, међутим, дању при сунчевој свјетлости, Аафинина сјена могла би да се створи само у њеној соби, док би се у ријеци могла видјети само сјена куће, али не и Аафинина. Ова нелогичност постаје упадљивија узме $и$ се у обзир Аа се у Сеобама уз појаву сјенке као физичког објекта скоро увијек указује на извор свјетлости, по принципу сликарске технике кјаро-скуро. „Запамима је жижак, који осветли и њу, сву, и његову огромну сенку на зиду” (Црњански 1978: 11) „Ватре су још шараме по мраку велике сенке и причине” (Црњански 1978: 13). „После када се појави Месец, постала је читава једна страна земье светла и, под мрачним брегом читава непрегледна поьа видна [...] Сасвим близу, иза плотова последњих сокака, учини им се Аа шећу безбројне, шарене сенке” (Црњански 1978: 25). „Пиамен жишка са пећи, осветьавао је велику избу, као са брега. Сенке ствари биле су зато огромне” (Црњански 1978: 68). Поред секундарних значења која добија у датим контекстима, сјенка у наведеним примјерима чува своје денотативно значење, потврђено присуством извора свјетлости (свијећа, логорска ватра, Мјесец). Његово непостојање у примјеру Аафининог оглеАања у ријеци указује на то да сјенка нема рјечничко значење, већ да је оно секундарно моделовано. Ово се значење у истом поглавьу декодира. „Схватила је зачас да ће поружнети, збабати се, да ће се кроз који дан вући као сенка” (Црњански 1978: 85). У овом контексту 'сјенка' не означава реалну физичку појаву, већ се као њени значењски еквиваленти јављају појмови поружнети, збабати се, као што се поредбеним путем поистовјећује са самом Аафином. Аакме, у роману Сеобе сјенка остварује најмање двије врсте значења: 1) примарно, физичке појаве и 2) секундарно, значење промазности, као супротност звијезди из бескрајног плавог круга, која означава вјечност, на основу чега се може закьучити да је у ријеци Аафина заправо видјела саму себе, односно свој одраз метафорички поистовијећен са сјенком.

У Аругом поглавьу рада истакнуто је да у систему Црњанског 'сјенка' преАставьа једну од ознака барока. Она је такође једна од најфреквентнијих мек- 


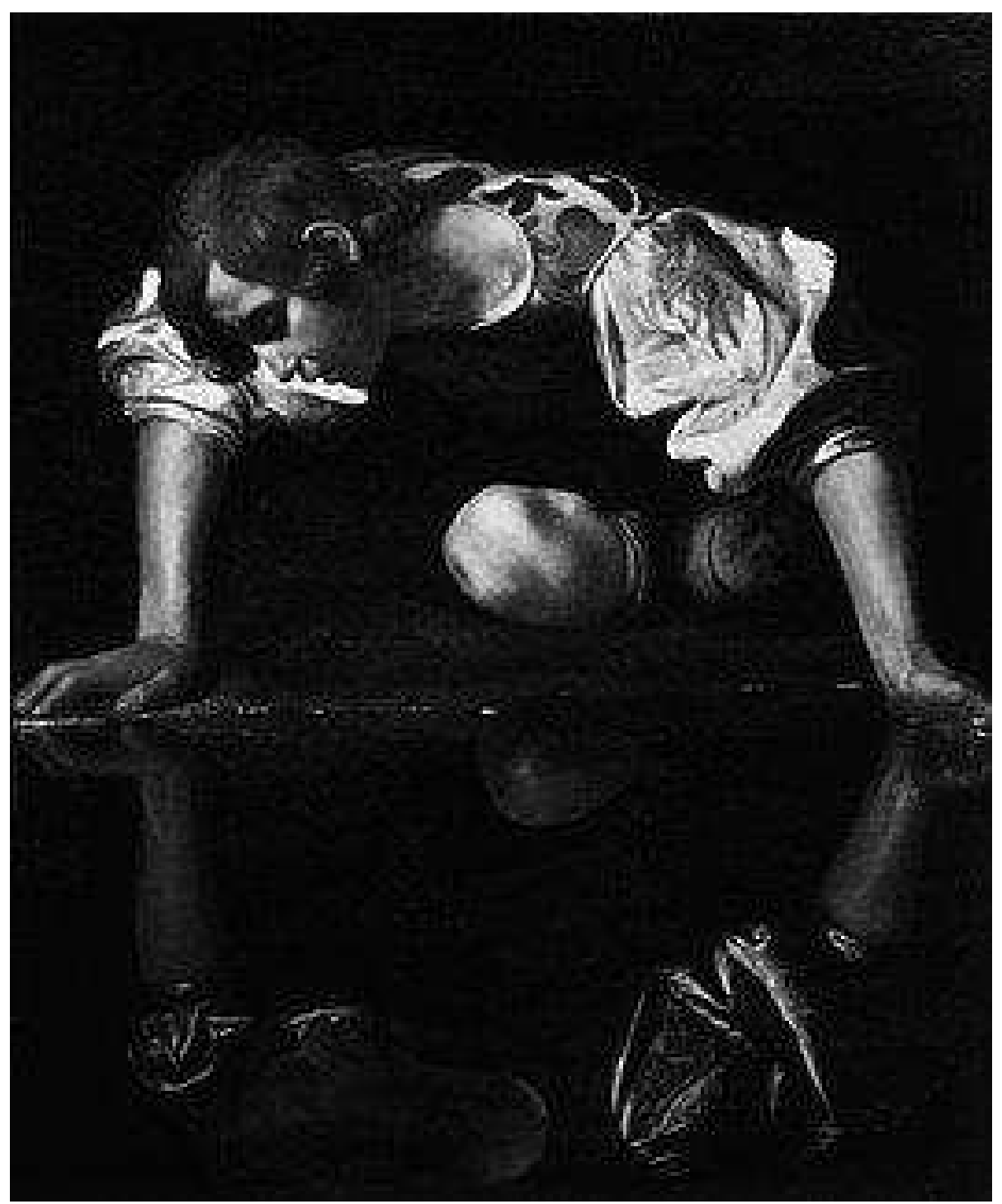

сема у његовом дјелу, чиме се остварује широк спектар значења, „ta reč svojim simboličnim značenjem sugerira misao o dvojstvu sveta, nekad presečenog na bazi paradoksalne antitetičnosti (materijalnog i duhovnog)” (Vučković 1972: 104). Супротна значењска структура наслова првог и трећег поглавьа указује нам да је Аафина, за разлику од Вука, биће везано за материјалну страну свијета. Зато сјена коју види умјесто свога одраза наговјештава њену смрт.

Већ на портрету Ханса Буркхајма и његове супруге видјели смо примјер изобличавања одраза у огледалу. Осим тога, овдје долази до замјене огледала са функционацно еквивалентном рефцектујућом површином. Познат примјер из умјетности барока јесте Каравађов Нарцис, чија структура одговара сцени Аафининог сусрета са сјеном умјесто одраза. Иако вјерно пресликава његов изглеА, Нарцисов одраз је затамњен, док је сам миадић јасно освијетьен. Каравађов chiaroscuro поступак ствара Аистинцкију свијетло-тамно, која се, из контекста мита о Нарцису, преноси на релацију живот-смрт, упућујући 


\section{Федор Б. Марјановић}

тиме на пролазност ьепоте и земног живота. Специфичност коју Црњански уводи у односу на Каравађову слику огледа се у томе што је његова рефлектујућа подмога динамична. Супституент огледала је ријека која „тече”. Промјена типа површине, из пасивног у Аинамички, указује протицање времена, чиме се подвлачи барокност односа означавајућег (ријеке, огледала) и означеног (пролазности, времена).

Анализирана сцена представьа својеврсно предсказање Аафинине смрти, потврђено њеним Аругим сусретом с оглеАалом у осмом поглавьу, у којем и умире. Ако бисмо се послужики поетским изразом, могли бисмо рећи аа је она у огледалу умјесто одраза видјела своју смрт. „Видевши своје упале очи, страховито чело и сасушен врат, наслути и сву ругобу покривених својих удова и опет поче да плаче” (Црњански 1978: 181). У овој слици долази до проши-

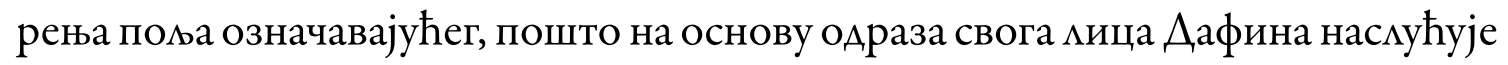
стање остатка свога тијела.

Међутим, присуство смрти у овој сцени не експиицира се само садржином огледала већ и његовом функцијом. „Са ужасом у укоченом погледу, заиска Аа јој се принесе огледало, оно исто огледацо, оковано у оквир од гвозденог цвећа, које су јој бабе, малопре, гураме под нос, да виде да ми још Аише” (Црњански 1978: 181). Значење смрти које носи огледамо појачава се чињеницом да је

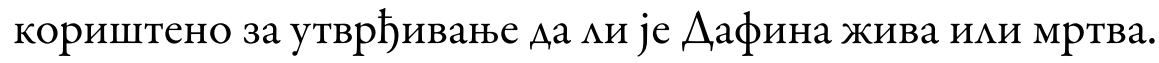

У оба случаја огмедало је носимац поруке memento mori, бимо као антиципација ими дословна блискост смрти. Аафинина сижејна минија грађена је поступком суптимних назнака њене будућности и равномјерно тече ка њиховој реацизацији. Као створење окренуто првенствено материјацном благостању, она се у роману појавьује крај Аранђела, док су тренуци њене среће у којима Аоживљава надземаљско стапање са природом и звијездама везани за прошлост, Вука Исаковича и њихова ноћна јахања. Као таква, она се у мужевим очима деградира из Аика идеанне ьепотице у мик досадне супруге, Аок пред дјеверовим и сопственим очима њена ьепота пропаАа. „Bez sumnje, jedan više intelektualni nego spontani stankovićevski manir omogućuje Crnjanskom da u elegiji i drami života žene odjedanput naglasi proždrljivost, lažljivost i žeđ za posedovanjem materijalnog, kao i senzualnu glad prevrtljive ženke” (Vučković 1972: 118).

\section{5. ВУково оглеАало}

Авије сцене у којима срећемо Вука Исаковича преА огледалом имају типичну структуру барокних vanitas мотива, с тим што се у Аругој сцени његова 
структура вишеструко усложњава, тако да сами јунаци преузимају функцију огледала.

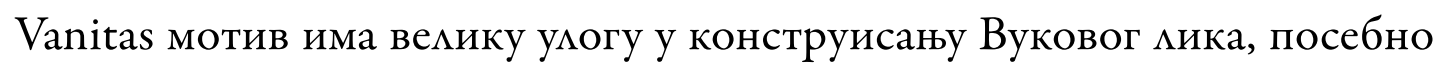
када је ријеч о његовој физичкој појави. Кроз опис Вукове незграпности у аустријском одијелу остварују се Авије значењске опозиције, које се рефлектују и у првој Вуковој сцени с огледалом. Као прво, упућује се на нескмаА између Ава система, аустроугарског и српског, који кроз цјелокупну Вукову сижејну минију долазе у међусобну комизију. Аок кроз призму српског пука преАјели које посјећују дјелују ново и зачуђујуће, а њихова улога у рату немотивисана, Аотле се они као Аруги описују из перспективе неколико аустроугарских микова, Комесара, Карла Аотариншког и барона Беренкмауа, који, иако разАичито посматрају пук, у њима виде средство ратовања. Ово имаголошко питање Аругости, преноси се и на огледало као један оА специфичних знакова аустроугарског система. „Мада је хтео, и требао, Аа пожури, чинио је бесциьне покрете и прекидао облачење дугим посматрањем себе, у огледалу, какво коА куће никаА видео није” (Црњански 1978: 31). Апозицијска реченица „какво код куће никаА видео није” проширује семантичко пове огледала. Оно више нема функцију објекта који рефмектује, већ је поставьено као супротност огледалима која је Вук виђао код куће, чиме се реализује опозиција аустроугарско-српско. С тим у вези, отуђеност коју Вук осјећа према свом одразу није само производ његових унутрашњих превирања него и његове позиције странца у односу на околину у којој се нацази. Тренутак када се Вук посматра у огледацу, које представьа знак аустроугарског система, заправо је тренутак када он самог себе види кроз призму тог система и када почиње судар између његове унутрашње самоспознаје и спознаје кроз призму Аругог.

На плану садржаја огледама остварује се опозиција између онога што би Вук желио Аа буде, тј. онога шта је био, и шта јесте и тренутку приповиједања. Опозиције прошиост-садашњост, младост-старост преносе се на психолошки поступак обликовања Вуковог мика, на супротност унутрашње-спољашње, при чему унутрашње преАставља начин на који Вук види самог себе, своје идеално Ја, док спољашње представьа његово реално стање, његов изглед и могућности. Сусрет с одразом у огледалу представља Вуков сусрет са својом спољашњошћу и иницијатора колизије унутрашњег и спољашњег у Вуку. Овим се прелази са спољашњег контекста огледаца на оно шта Вук види у њему.

У овом случају огледало означава Вукову подвојеност. „Навцачећи своје црвене чохе, њему се потпуно учини да се то обцачи неко Аруги, а не он, и Аа ће то неко Аруги саА изићи, накинђурен, из те собе, а не он” (Црњански 1978: 
31). Подвојеност која се у овом случају остварује у односу Вука и његовог одраза интернализује се у каснијим дијеловима романа:

Све то прошло је тако бесмислено Аа се Вуку Исаковичу чинияо као Аа постоје Ава Вука Исаковича: један који јаше, урла, маше сабњом, гази реке, трчи по гунгули и пуца из пиштоља, идући према Мајнцу, или зидинама Аујевих утврђења, који су се јасно оцртавали над водом, док убијени паАају и остају на земьи; и Аруги, који мирно, као сенка, корача крај њега и гмеда и ћути (Црњански 1978: 142).

У оба описа разликују се два Вука Исаковича: 1) активни, који одмази из собе и води ратне походе и 2) пасивни, који се своди на умогу посматрача свога оАраза и сопствених дјела у рату, који је, попут госпоже Аафине, постао сјенка. Исаковичев мик се располућује на нивоу спољашње-унутрашње, активно-пасивно, упућујући тиме на то Аа постоји велики раскорак између његових Ајела и његовог разумијевања тих дјема. Ово стање располућености произикази из Вуковог осјећања Аа његов живот (Ајела, његова улога у рату) не припадају њему самом, нису дошии из његове самосталне одлуке, већ „Аругоме, што је требао само Аа духне, па Аа он потрчи без обзира, преко брда и река, на све стране, не питајући ни колико бола тиме себи наноси, ни какав ужас за собом оставља, ни у какво кудимо преА собом залази" (Црњански 1978: 100).

Аруги, који Вука шање у рат којем не зна циња ни повода, у роману се остварује кроз неколико мица. Он преузима апстрактни мик Марије Терезије, која се физички не појавьује у роману, ами чије се присуство осјећа на војним вјежбама, официјелним аудијенцијама и походима, или микове конкретних војсковођа као што је Кармо Цотариншки. У тим случајевима ради се о сукобу система српско-аустроугарско у самом Вуку, односно сукобу између његовог националног идентитета и војничке службе и дужности према народу којем не припада. У Аругом скучају, који обухвата опозиције унутрашње-спољашње, cogito-agito, Вук је Аруги, тј. његов мик у огмеАалу, његова сопствена појавност и дјелатност, он сам ван себе.

Вукова огоњеност док стоји испреА огмеАала служи као интензификатор стања његове расцијепьености. Тиме се читаоцу упућује Аа његова отуђеност оА себе самог није условљена аустријском униформом која нескцадно стоји на његовом тијеку, већ да она обињежава однос његовог ума и тијела, које се у његовој перспективи појавьује парцелизовано и отуђено од њега самог. „Вецики комади његових груди и ногу, а нарочито трбух, дођоше му у оглеАалу смешни и туђи" (Црњански 1978: 31). 
Вукова расцијепьеност на спољашње и унутрашње, тј. на тјелесно и духовно, има и своју временску конкретизацију. Ту се као важна ознака јавља његов „широк ожиьак ране, на десном рамену” (Црњански 1978: 31). Иако у опису Аиспропорционалности Вуковог изгледа Црњански највише користи пренаглашавање његовог стомака, сликовито га поредећи са мијехом и буретом, ожиьак, скривен испод слоја Вукове барокно накинђурене одјеће, постаје један од главних знакова Вукове унутрашње подвојености. Из перспективе госпоже Аафине овај ожиьак је обиьежје рата. „ОАлазио је у рат, у нешто потпуно несхватьиво и ужасно за мозак госпоже Аафине, коју је, при самој помисли на онај његов страшни ожиьак оА сабље припадаца мука" (Црњански 1978: 77). Гађење које Аафина осјећа према Вуковом ожиьку представьа оАступање од уобичајених Аафининих осјећања према супругу. Оно се свакако може довести у еквиваценцију са гађењем које је Аафина осјетима према самој

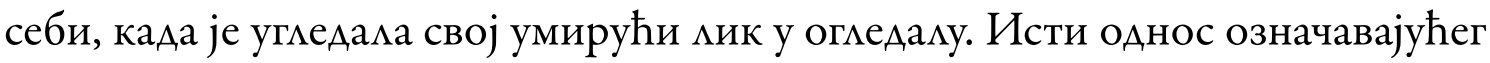
и означеног понавьа се из Вукове перспективе. „Са оном страшном раном што му се протезаца од гркьана до десног рамена, зар није узалуд, месецима, межао непомичан, наА утоком Аунава, мебдећи између живота и смрти, у оку са жутом светлошћу разцивене воде, песка и врхова јабланова" (Црњански 1978: 101). У оба случаја ожиьак је знак рата и смрти. Његово наглашавање у сцени с огледалом стога се може схватити као упућивање поруке memento mori. Међутим, хронолошки, Вук је ожиьак задобио у току свог трећег ратног похода, након којег му умире отац и у њему се јавьа осјећање апсурда и досаде. Тако ожиьак не представља само знак смрти већ својеврсну границу између Авије етапе Вуковог живота, која ће представьати основ његове подвојености.

Граница између два доба развија се као опозиција младост-старост. Ова супротност долази до своје конкретизације у шестом поглавьу, у којем се Вук преА огледалом сусреће са супругом Карла Александра Виртембершког. Значење овог поглавьа већ је Аато у његовом наслову: „Прошлост је грозан, мутан бездан; што у тај сумрак оде, не постоји више и није никаА ни постојало” (Црњански 1978: 114). На овај начин, као једна од основних тема поглавьа поставьа се вријеме. У тој функцији јавьа се и огцедало, као једна од ознака пролазности времена, коју је имаха и у бароку.

Заправо, конструкција читавог погмавьа постављена је по принципу оглеАала. Тематски се могу разАиковати два дијела - један који описује прошлост, а други садашњост - при чему се садашњост може сматрати изокренутом сликом прошлости. Ова изобличеност не остварује се само кроз трансформацију главних јунака поглавља, Вука Исаковича и принцезе, већ се огледа и на многим 
мањим значењским јединицама, које се поставьају у систем опозиција, оА којих је једна представьена кроз године Вука Исаковича. У Аијелу у којем се описује прошиост он је „најмиађи у пуку” (Црњански 1978: 116), док је у Аијелу у којем се описује садашњост он најстарији у Аунавском полку (Црњански 1978: 123). Из ове релације опозиција прошлост-садашњост значењски се проширује на младост-старост. Вукова расцијепьеност, која почиње сценом у оглеАалу, у овом се погмавьу остварује на нивоу расцијепьености између мцадог Вука и старог Вука. Као онај који припада садашњости, старац је онај који припада активној сфери Вуковог бића, као и спољашњој, пошто га принцеза види као старца. МцаАи Вук је онај који се претворио у сјену и који остаје у духовној сфери Вуковог бића као идеацна слика самога себе. Ова супротност преноси се

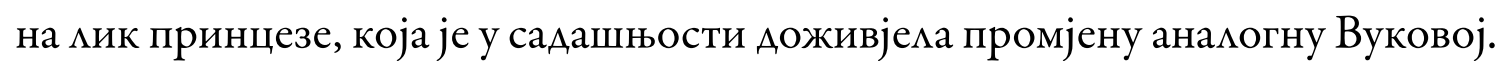
Овим се истиче значење пролазности времена, тим више што је опозиција између принцезиног изгледа у прошлости и садашњости оштрије описана него када је у питању Вук.

Огледало се у поглавьу појавьује у дијелу у којем се описује садашњост. Аок је у првој сцени с огледацом истакнута његова страност у односу на национа но-културни миље из којег долази Вук Исакович, у овом случају пренаглашавају се димензије огледаца, тако Аа оно постаје знак промјене која се десима у прелазу из прошлости у садашњост. У садашњости, Вук принцезу угледа први пут у огледацу. Али његове Аимензије су толике да у њему Вук види и себе и све што га окружује:

Смешећи се збуњено, као да се осећаше нешто крив, Вук Исакович је био тим неспретнији што је у огледацу, пред којим је стајала, видео самога себе, и што је, за њим, непомично, слушаца њене речи читава група Срба, официра, који су дисаци тако дубоко да се то чуло, и да је њин дах осећао на вцасима, у потиьку.

Видевши у огледалу, великом као капија, зидове, као млеком опране, позмаћене; таваницу пуну белих анђела и пастира, са задигнутим и приАенутим сукњама, тако да им је за тренутак видео ружичаста колена; бакарне светњаке, са искованим мишћем и маким анђелчићима, пуне безбројних свећа, Исакович, упцашен, видео је и њу, у огледалу, међима окренут, пре него што јој погмеда у мице (Црњански 1978: 121).

Огледало у овом случају гута цијели свијет. Оно указује на то да је направьена Аисторзија у односу на сентименталну ьубавну причу из Вукове младости и да је преласком из једне сцене у другу дошио до преокрета. Зато се читава 
околина око Вука, прициком сусрета са принцезом, прво описује изокренута у огледалу. Притом посьедња која се описује у тој слици јесте принцеза. Његов пук и барокни декор заправо су оно што је испунимо вријеме и простор између њиховог претходног сусрета. Поред тога, раскош декора, супротан од изгеда Авоје оронулих ьубавника, носи функцију типичног барокног vanitas мотива.

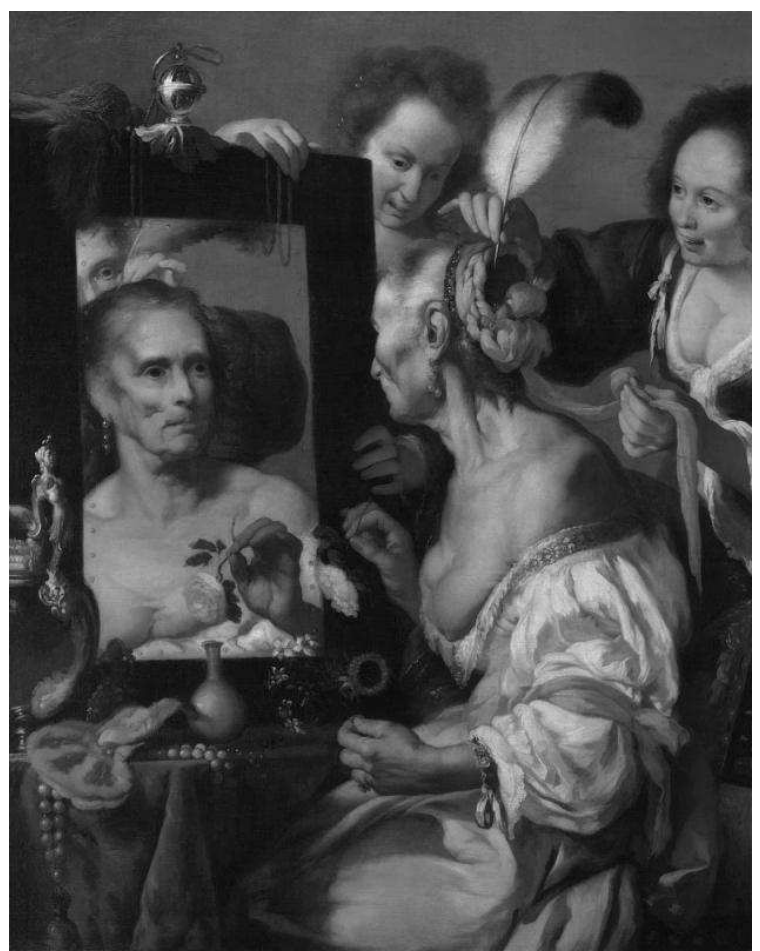

Суштински, овај мотив је потпуно остварен у опису остарјеле принцезе. Његова барокност може се илустровати поређењем са сликом Бернарда Строција Cmaра кокета ими Vanitas. Вук заправо измијењену принцезу види Ава

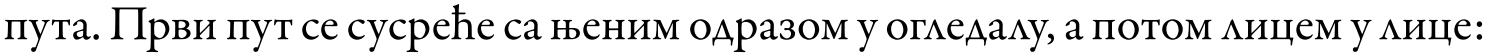

Бима се обукца као млада девојка, имаца је на глави читав пласт косе, који је био повезан белом траком и висио позади као уврнут коњски реп. Обнажена рамена сијаху јој се, као сасушене кости на сунцу, са удубљењима наборане коже, пуним белог прашка. $\Lambda$ еђа јој беху укочена и утегнута у оклоп од свиле, а струк тврА и округао, као стабло неке старе крушке, које је још само зато ту да би се на њега могме натаћи свимене сукње, широке и разапете као празан шатор, сав извезен цвећем и гранчицама, под којим нема ничег (Црњански 1978: 122).

Слика принцезе у огледацу потврђује се у стварности описом њеног изгледа у свијету реацности (насупрот њеном одразу). Јасно је да је читав контекст, почевши оА принцезине околине па до њене тоалете, структурисан аналогно Строцијевој слици. Свакако, не желимо дати претпоставку да је Црњански 
ову сцену градио према барокној слици, са којом можда није био ни упознат. Поређењем Строцијеве слике са сценом из Сеоба потврђује се да је Црњански вјерно преузео коิА барокног језика и уградио га у језик сопственог дјела, које припада авангардној традицији српске књижевности. ААи инвентивност ове сцене не своди се на чисто прекодирање одређене знаковне структуре из јеАног система (барока) у други (авангарду), већ и његово функционацно проширење.

Наравно, у оба скучаја огледало је кьучни симбол који рефлектује значења свих осталих чланова система. Али док у Строцијевој слици оно означава непоАударност стварности (старичиног одраза) и њене визије саме себе (њене тоамете и накита, пауновог пера, типичног симбола таштине), у Сеобама функција огледала се умножава. Вукова оронулост није означена само његовим одразом него и принцезином оронулошћу, и обрнуто. ПореА тога, и сами јунаци функционишу као својеврсна огледаца. Прицезин опис са којим се читацац сусреће заправо је њен одраз у Вуковим очима (чију перспективу нарација прати), исто као што се и његов изглеА огледа у принцезиним реакцијама.

„Гедајући га са подсмехом и она беше зачуђена његовим кривим ставом, отромбољеним устима и брцима и погледом уморним, а нарочито јој сметаше што се непрестано премештао с ноге на ногу. И њој се, као и Аругима, учини као неко одевено буре, шупье и празно” (Црњански 1978: 123).

Никола Мимошевић је већ уочио да у опису Вука и принцезе у тренутку садашњости приповиједања доминира техника опредмећивања: „Посредно, овај метод служи за сугерисање трагичне поруке о неумољивој пролазности

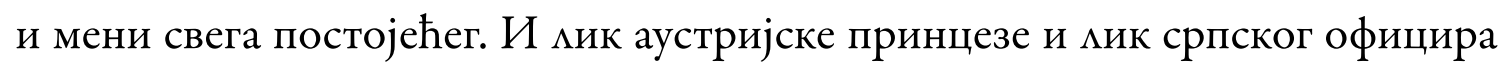
Исаковича једнако меланхолично сведоче ту стару и суморну истину" (1988: 124). Поред овога, не смије се прећи преко технике упоређивања, која има исту функцију: „Та техника упоређивања - контрастирања комично, потом натуралистички оштро, саркастично, упозорава на тријумф пролазности, посебно ммадости и еротске снаге, и на смешне амбиције једне страсти која на неки начин жуди за имузијама миадости” (Аеовац 1981: 68).

Аок се техника опредмећивања остварује на микроелементима поглавља (појединачним описима), техника упоређивања проширује се на конструкцију цијелог поглавља, тако Аа опис Вукове и принцезине младости стоји као антитеза њихове садашњости. Вуковом старачком изгледу супротан је његов опис из младих Аана, приказан из принцезине перспективе. „Вук Исакович био је у том тренутку меп, својим грозничавим очима, боје старог зАата, и својим по- 
модрелим уснама, под гаравим, змијски опуштеним брцима, који су за њу били нешто тако необично” (Црњански 1978: 118). Исто тако, принцезин изглеА у младости контраст је њеном изгледу у старости. „Чим би он ујутру дошао на службу, она би, као случајно, прошла без перике, са својом уковрџеном, кратком косом, црном као у ђаволице, разголићених груди, погледавши га, кроз морњон, јеАним оком, тако Аа би он стао укопан, да одмах затим побледи и разрогачи очи, загледан нетремице у њу” (Црњански 1978: 115). Тиме се ствара још једна паралела са Строцијевом сликом, која је настала као барокна пародија Тицијанове слике Венера пред огледалом. Структурни однос Авију слика остварен је у шестом поглавьу Сеоба у опису Вукове прошлости и садашњости, односно његове ьубави са принцезом и сусрета тридесет година касније. Релација ренесансе и барока овдје се остварује као однос препорођења и пропадања, што је један оА основних конструктивних принципа шестог поглавља романа Сеобе. Јунаци у ммадости, аналогни мику Тицијанове Венере, тридесет година касније преображавају се у мичности анацогне Строцијевој старој кокети. Уз поменуте vanitas мотиве, који окружују Вука и принцезу, огмеАало у овој сцени има све одиике означавајућег које је имамо у језику барока.

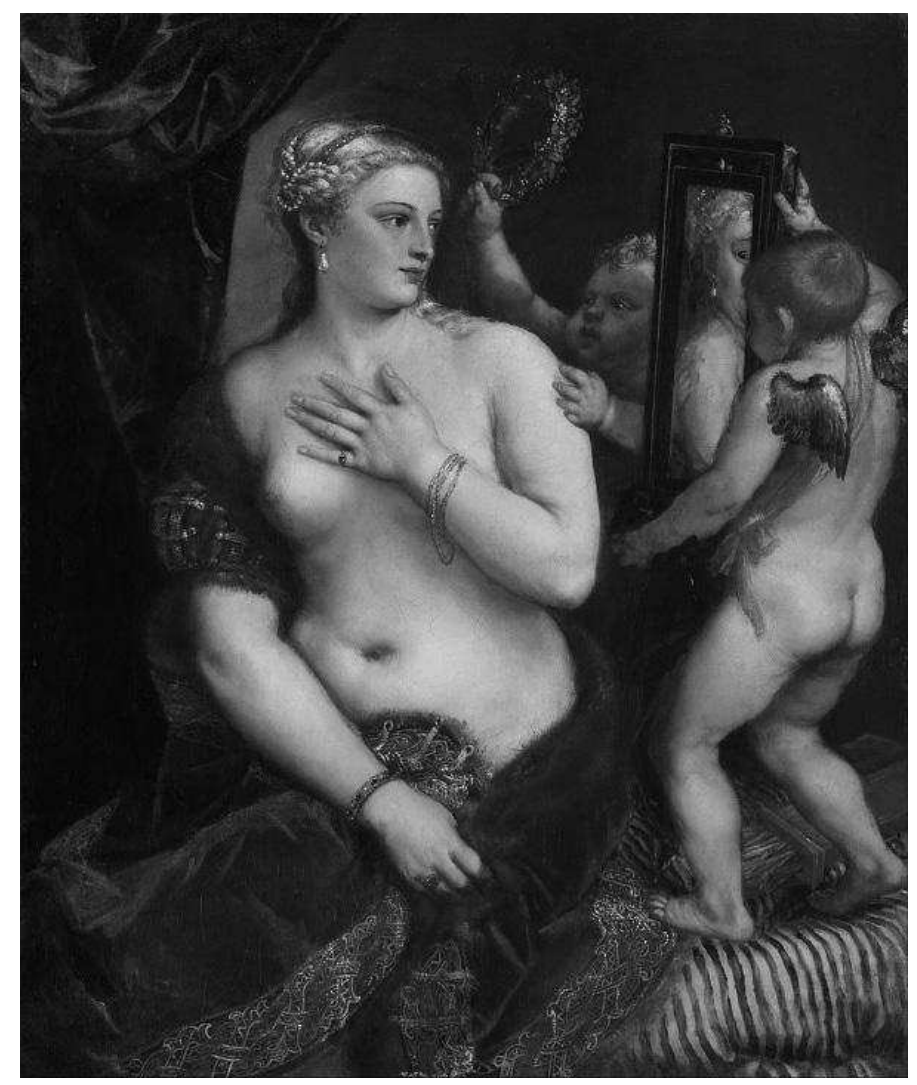

На плану психолошке слике Вука Исаковича, у овој сцени његова је поАијељеност конкретизована у миковима ммадог (који остаје у Ауховној Аи- 
мензији јунака) и старог Вука (који се испољава кроз његову тјелесну слику). Иако овај однос одише „барокним” осјећањем меланхолије, на крају романа, у Вуковом сну, Аолази до хармоничног стапања Вукове кичности у цјелину, наглашавањем да је јунак „у телу” сачувао „последње зрно некадање младости”, које се поистовјећује са звијездом у бескрајном пцавом кругу: „Зрно што је и у његовој старости у себи сачувало моћ да прокмија и наднесе нова бића над времена и небеса, која ће се огледати у водама што се сливају и састају, ту, испоА Турске и Немачке, огледати и надносити као мостови" (Црњански 1978: 250).

У цитираној реченици којом се завршава роман, поново се појавьује мотив огледала, али овог пута не у облику предмета, већ као апстрактна радња („огмеАање”), која надикази границе Вуковог тијела. Крај романа заправо преАставља оправдање Вукових патњи и апсурда с којим је био суочен. Као што зрно мхадости надимази тјелесне границе његовог тијела, оно надимази и временске границе његовог живота и преноси се на његове потомке. (Овакав крај можемо тумачити као антиципацију Аруге къиге Сеоба.) У таквом контексту огледало, односно „огмедање”, више није означитељ располућености, већ повезивања.

\section{6. Закьучак}

У нашем истраживању увидјели смо да је значење које Црњански даје бароку саАржински супротно схватању историјског периода високог барока ими рококоа и философије просвјетитеьства, који је описан у Сеобама. За Црњанског истински барок представљају умјетничке тенденције које открива у дјелу Микеланђема. Стога огледало као семантички знак преноси исто значење које је преносимо у наведеним књижевним и сликарским примјерима барокне умјетности XVI вијека. Иу бароку и у Сеобама огмедамо је означитељ пролазности.

Јунаци који се срећу с огледалом јесу госпожа Аафина и Вук Исакович. Аналог слици Аафине која свој одраз у ријеци види као сјену јесте Каравађов Нарцис, у којем је одраз осликан тамнијим бојама у односу на Аик Нарциса. Поистовјећивање Аафининог одраза са сјеном антиципира њено скоро претварање у сјену, односно пропадање и смрт, док ријека која, за разАику од језера у Каравађовој слици, тече симболизује протицање времена, што је још једна значењска димензија огледала у језику умјетности барока. У Аругој сцени с огледалом порука тетеnto mori Аијелом се остварује функцијом коју огмедало има у утврђивању живота или смрти. Такође долази до проширења 
подручја означеног, па се значење Аафининог одраза, као означитеьа њеног пропадања, преноси на друге Аијелове тијела, који нису одражени у оглеАалу.

Када је у питању Вук Исакович, огледацо има Авоструку функцију. Осим што означава пролазност, оно служи и као означитеь располућености његове Аичности. Подвојеност Вука Исаковича обухвата много нивоа, који иду оА ширег национацног контекста, српско-аустроугарско, Ао приватног контекста Вукове расцијепьености на оно што осјећа и оно што јесте, Ауховно-тјелесно, унутрашње-спољашње, пасивно-активно и младост-старост. Посьедња супротност конкретизује се у шестом погцавьу, када се након описа његове младалачке ьубави са супругом Карла Александра Виртембершког описује њихов сусрет тридесет година касније. Чињеница Аа Вук себе и принцезу прво види у огледалу, упућује читаоца на дисторзију његове садашњости у односу на прошлост. Сам декор, принцезина тоалета и Вуково одијело имају функцију типичних vanitas мотива, који су у контрастној позицији у односу на њихов изглеА. У овој сцени заправо Аолази до јеАног оА најАиректнијих сукоба између високог барока (спољашњег декора) и барока Црњанског (унутрашњег).

\section{Извори:}

1. Црњански, Мимош (1978), Сеобе, Београд: Нолит.

2. Црњански, Мияош (1999), Есеји и чланци I, Београд: Задужбина Мимоша Црњанског, Laussane: L'Age d'Homme.

3. Црњански, Мимош (1999), Есеји и члании II, БеограА: Задужбина Мимоша Црњанског, Laussane: L’Age d'Homme.

4. Црњански, Мимош (2008), Кюига о Микеланђелу, Београд: Штампар Макарије, Подгорица: Октоих.

\section{Митература:}

1. Velflin, Hajnrih (2000), Renesansa i barok, Sremski Karlovci - Novi Sad: Izdavačka knjižarnica Zorana Stojanovića.

2. Vučković, Radovan (1972), Književne analize, Sarajevo: Zavod za izdavanje udžbenika.

3. Janson, H. W. (1970), Istorija umetnosti, Beograd: Izdavački zavod „Jugoslavija”.

4. Ковевић, Светозар (2007), Вавилонски изазови, Матица Српска: Нови СаА.

5. Larousse - Mali rečnik simbola (2011), Beograd: Laguna.

6. Меовац, Славко (1981), Милош Црғански романсијер, Сарајево: Свјетлост.

7. Мимошевић, Никола (1988), Роман Милоша Црнанског: проблем универзалног исказа, Београд: Нолит. 
8. Миочиновић, Мирјана (2005), „Маска Мимоша Црњанског”, Кғига о Црғанском (ур. Мимо Аомпар), БеограА: Српска књижевна задруга, 225-254.

9. Opća povijest umjetnosti (2006), Zagreb: Mladinska knjiga.

10. Петковић, Новица, Ава српска романа, интернет, доступно на www. antologijasrpskeknjizevnosti.rs (приступьено 15. августа 2009).

11. Раичевић, Горана (2005), Есеји Милоша Црғанског, Сремски Карловци - Нови СаА: Издавачка књижарница Зорана Стојановића.

12. Todorović, Jelena (2012), O ogledalima, ružama i ništavilu, Beograd: Clio.

\title{
THE BAROQUE MIRROR MOTIVE IN THE NOVEL MIGRATIONS BY MILOŠ CRNJANSKI
}

\begin{abstract}
Summary
The topic of this paper is the mirror motive in the novel Migrations by Miloš Crnjanski. In the specific use of this motive, baroque influences can be recognised. The first part of this paper focuses on the meaning of baroque in the work of Miloš Crnjasnki. The second part brings to light the symbolic values that the mirror reflects in baroque art through the examples of Dživo Bunić' and Giovanni Canalle's poetry and paintings by Lucas Furtenagel and De la Tours. In Crnjanski's novel, the mirror is used as a symbol of transience of life and death. In the construction of Dafina's character the mirror symbolises the anticipation and realisation of her decay. Also, the mirror represents the duality of Vuk Isakovic's character. Works of baroque painters such as Caravaggio and Bernardo Strozzi are used as examples within the analysis.
\end{abstract}

